\title{
How Does Owners' Exposure to Idiosyncratic Risk Influence the Capital Structure of Private Companies?
}

\author{
Elisabeth MuelleR*
}

February 28, 2005

\begin{abstract}
This paper identifies the entrepreneur's exposure to idiosyncratic risk as an important determinant of the capital structure of private companies. The exposure to idiosyncratic risk is approximated by the share of personal net worth invested in one company (SNWI). Exposure to idiosyncratic risk increases cost of equity capital since higher equity returns are required as compensation. This makes bank financing more attractive. We find that SNWI increases the demand for new bank loans whereas we cannot identify an effect on the supply. Equilibrium values of leverage increase significantly in SNWI but there is no effect on the equilibrium interest rate.
\end{abstract}

JEL classification: G30, G32

Keywords: entrepreneurial investment, capital structure, underdiversification, private companies

This paper should be considered for the Young Economist Award.

*Centre for European Economic Research (ZEW), Department of Industrial Economics and International Management, L7,1, 68161 Mannheim, Germany, e-mail: Mueller@zew.de

Acknowledgements: I would like to thank Ron Anderson, Georg Licht, Steve Nickell and Tereza Tykvova for their helpful comments. 


\section{Introduction}

Private companies have typically only a limited number of owners, each with a large ownership share. The concentrated ownership helps to overcome control problems caused by the opaqueness of the business operations. However, it also exposes owners to idiosyncratic risk, since they often invest a high share of their personal net worth in a single company. Their personal portfolio is therefore not well diversified. The degree of underdiversification can be described by the share of net worth invested in one company. If owners require a compensation for their risk exposure, they have to demand higher returns on their equity investment, which is equivalent to higher costs of equity capital for the private company. The higher costs of equity capital makes bank financing relatively more attractive. We therefore expect that the degree of underdiversification has a positive effect on leverage. The main point of this paper is an investigation of how owners' exposure to idiosyncratic risk influences the capital structure of private companies. In order to deepen our understanding of the mechanisms at work, we also investigate the effect of underdiversification on loan applications, loan approvals and the interest rate of loans. Tests for the capital structure have so far neglected influences that stem from the specific ownership structure of private companies.

The degree of underdiversification is quite substantial in private companies. Moskowitz and Vissing-Jørgensen (2002) document that, on average, owners of private companies have invested $30 \%$ of their wealth in just one company. This high degree of underdiversification increases the cost of equity capital for private companies as shown by Kerins et al. (2004). The authors employ the CAPM to simulate the cost of equity capital for an underdiversified entrepreneur who is able to invest in both the own company and the stock market using an investment solely in the stock market for comparison. The relative weights of the investment in the company and the stock market determine the total risk of the portfolio. The total risk can be duplicated by borrowing money and investing the own resources and the borrowed money in the stock market. The expected returns on such a levered market investment is the opportunity cost of equity capital for an underdiversified entrepreneur, which is calculated for different assumed levels of underdiversification. The model predicts an increase of 9.8 percentage points in the opportunity cost of equity capital for a small company if underdiversification increases by $10 \%$. This is a substantial increase considering that annual returns for public equity, as calculated by Moskowitz and Vissing-Jørgensen (2002), are 11.0\%, 14.6\% 
and $24.7 \%$ for the time periods $1990-92,1993-95$ and $1996-98$ respectively. The returns to public equity can be used as a benchmark for the cost of equity capital if investors can diversify, since the returns do not include a compensation for exposure to idiosyncratic risk.

The large effect of underdiversification was not only found in the simulation by Kerins et al. (2004), it was also shown that higher underdiversification is related to higher realised equity returns for a sample of private companies in the US (Mueller (2004)). Profitability increases since owners require higher returns as a compensation for their exposure to idiosyncratic risk and owner-managers work more since they are more dependent on the success of the company. For owners unrelated to management, the study finds an effect of underdiversification similar in size to the results of Kerins et al. (2004). An increase in underdiversification of 10 percentage points increases the return on equity by 9.2 percentage points. Both the simulation and the empirical analysis show that the influence of underdiversification is substantial.

The main topic of this paper is the influence of owners' exposure to idiosyncratic risk on the capital structure of private companies. Empirically, we can only identify the reduced form for leverage, since we have no variables that would shift only the demand or only the supply function of leverage. However, since we observe applications for new loans and the approval or denial of loan applications, we can infer whether demand or supply forces drive a change in leverage in the reduced form. Leverage is the result of decisions on bank financing over time; in this sense it is a stock variable. We gain a deeper understanding of the determinants of leverage by investigating the determinants of the flow variables loan application and loan approval as well.

The empirical analysis of this paper is based on the Survey of Small Business Finances (SSBF) from the year 1998. The survey is well suited for our analysis since it provides information both on the financial structure of private companies and the personal wealth of their owners. It allows us to study the demand for new bank loans since we observe whether a company has applied for a new loan in the three years preceding the survey. The supply of new loans is included as well. We know whether the loan applications three years prior to the survey were approved or denied. In addition, it includes detailed characteristics of the most recent loan. The survey reports the interest rate, whether a fixed or a variable rate is used and whether collateral is required. Since we observe total debt and total assets, we 
can calculate the capital structure of private companies. We measure underdiversification empirically as the share of personal net worth that the largest owner has invested in his or her company $!^{1}$

Several hypotheses about the consequences of underdiversification for the financing of private companies are tested. Since underdiversification increases the cost of equity capital, we expect a higher demand for bank financing from more highly underdiversified owners. This would be the consequence if owners try to equalise the marginal cost of equity and debt capital. A more extensive use of bank loans helps to reduce the financial commitment of the owner. Our first hypothesis is that owners with a higher degree of underdiversification exhibit a higher probability of applying for a new loan. Since profitability is increasing in underdiversification, we also expect that the supply of loans increases with underdiversification. Banks have no disutility from the underdiversification of the owner but gain from higher profitability, so they should be willing to lend more. We hypothesise that underdiversification increases the probability of loan approval. We have no clear expectation with regard to the change in the interest rate. If the demand function is decreasing in the interest rate and the supply function is increasing in the interest rate, then the consequences of an increase in underdiversification for the equilibrium interest rate is unclear. The effect depends on whether demand or supply shifts more. With respect to leverage our expectations are unequivocal again. If both demand for and supply of bank loans increases in underdiversification, it follows that leverage increases in underdiversification as well. This is the central point of interest of this paper. Higher cost of equity capital for owners with a higher degree of underdiversification should lead to a more extensive use of bank financing reflected in higher leverage.

Most of the hypotheses are confirmed by the data. More underdiversified owners confronted with higher costs of equity capital evince a higher demand for bank loans. The probability that a company makes an application for a new loan in the three years preceding the survey is increasing in underdiversification. For supply of loans we find no effect of underdiversification, but we cannot exclude the possibility that underdiversification increases the

\footnotetext{
${ }^{1}$ This study has been widely used for empirical analysis, see, for example Berger and Udell (1995) and Petersen and Rajan (1994) for studies on lending relationships or Ang et al. (2000) and Bitler et al. (2005) for analyses of agency conflicts in private companies.
} 
supply of loans insofar as underdiversification is used to signal company profitability. We do not find a significant influence on the equilibrium interest rate which is consistent with two possible market constellations. Since we find an increase in demand we conclude that either supply is increasing as well to offset the effect of an increase in demand or that the supply function is flat in the interest rate and not shifting in the share of net worth invested. As hypothesised, the degree of underdiversification has a positive and large effect on leverage. A one standard deviation increase in the share of net worth invested leads, ceteris paribus, to an increase in leverage of 18.5 percentage points. This is substantial, especially when considering that average leverage in the sample is $32.6 \%$. Underdiversification is therefore an important determinant of the capital structure of private companies.

The empirical results have important implications for our understanding of the financing of private companies. We find that entrepreneurs who are more exposed to the idiosyncratic risk of their companies use bank financing more extensively. Bank financing allows them to grow their companies without increasing their risk exposure further. Alternatively, entrepreneurs can use bank financing to reduce their own investment if they keep company size constant. Since exposure to idiosyncratic risk increases the cost of equity capital and accordingly the required returns of an investment project, this also means that the availability of bank loans makes the realisation of some investment projects profitable that would not be realised in its absence. Bank financing decreases the returns that are required for the realisation of an investment project.

This paper studies how the degree of underdiversification, one characteristic of the financial situation of owners, affects the capital structure of a private company. There is a related literature studying other aspects of owners' financial situation. Cressy (1996) analyses data on bank overdrafts from UK startup companies with respect to loan conditions and company survival. He finds that banks agree to higher overdraft limits if more collateral, measured as house equity, is available. Furthermore, it is evident that survival probability is increased if an entrepreneur used personal funds in starting up. Cavalluzzo and Wolken (2002) also test whether personal wealth affects the availability of bank loans. The authors find that greater private wealth increases probability of loan approval since personal assets can be used as collateral for business loans.

This paper is also related to the literature studying the determinants of the capital struc- 
ture of private companies. Up to know, this literature has not taken the financial situation of the corresponding owners into consideration. Giannetti (2003), for example, focuses on differences between countries. The study aims to identify the importance of legal rules and financial development for capital structure. One of the results is that companies in countries with institutions favouring creditor rights have, on average, higher leverage. Chittenden et al. (1996) concentrate on the influence of company characteristics. The authors find a negative effect of profitability, size and age on the leverage of private companies. The ability to provide collateral from inside the company is proxied for by the ratio of fixed to total assets, which has a positive effect.

The remaining part of this paper is structured as follows. Section 2 develops the hypotheses and describes the estimation strategy; Section 3 explains the data set and defines the variables; Section 4 shows the empirical results; and Section 5 concludes.

\section{Hypotheses}

In this section we derive the hypotheses that we are going to test. The main interest of the paper is the question of how entrepreneurs' exposure to idiosyncratic risk influences the capital structure of private companies. We approach this question in a step-wise procedure. We first derive hypotheses about how underdiversification affects the demand for and the supply of loans. Next we derive the implications of changes in demand and supply for the equilibrium interest rate. Finally, we bring our considerations together and develop a hypothesis for the relationship between underdiversification and leverage.

The simulation by Kerins et al. (2004) suggests that underdiversification, which is calculated as the share of net worth invested in one company, increases the cost of equity capital. The mechanism at work is that rational owners will demand a compensation for their exposure to idiosyncratic risk. Since owners who maximise company value will try to achieve equality of marginal cost of equity and debt capital, we expect that owners with a higher degree of underdiversification will demonstrate a higher demand for bank loans. Owners can use bank loans to reduce their own financial commitment in case the company does not grow or to grow the company without additional personal investment. We derive the first hypothesis accordingly: 
Hypothesis 1 (demand for loans): Owners with a higher degree of underdiversification exhibit a higher probability of applying for a new loan in a given time period.

It has been empirically shown that underdiversification is related to higher company profitability due to owners requiring higher returns and owner-managers working harder to ensure the companies' success (Mueller (2004)). Since banks do not suffer from the underdiversification of owners, rather gaining from the higher profitability involved, we expect that banks are more willing to lend to owners with higher degrees of underdiversification.

Hypothesis 2 (supply of loans): The probability of loan approval is higher for loan applications filed by more highly underdiversified owners.

In addition, we are interested in the effect underdiversification has on the interest rate of bank loans and on leverage. Interest rates and leverage are equilibrium values, a result of both the demand for and supply of external financing. Empirically, a structural model is needed to separately identify the demand and the supply function for external financing, in our case more specifically for leverage. Unfortunately, the data set does not include variables that would shift only the demand or only the supply curve. It is therefore not possible to identify the structural model. Nevertheless, we can calculate reduced form effects for interest rate and leverage and deduce from them how underdiversification affects the respective equilibrium values.

Owners who maximise company value will choose leverage such that the marginal cost of debt and equity capital are equal. Since we do not observe marginal costs of capital in our data, we use the interest rate of each firm's most recent loan as an approximation. This interest rate reflects the average cost of the firms' latest additions to debt finance.

Although the empirical analysis does not allow us to identify the coefficients of the structural model, it is nevertheless helpful to write it out since we can make predictions for the reduced form coefficients by hypothesising about the signs of the coefficients in the structural form. In the following simplified demand and supply functions, represented in equations (1) and (2), we consider underdiversification as the only shift variable to keep notation simple. Underdiversification is approximated by the share of net worth invested (SNWI). The variable ir stands for the nominal interest rate. It denotes any potential value of the interest 
rate that fulfills either the demand or the supply function. It is not an equilibrium value. $l e v^{d}$ and $l e v^{s}$ denotes demand for and supply of leverage $2^{2}$

$$
\begin{aligned}
& l e v^{d}(\mathrm{ir})=\alpha_{1}+\gamma_{1} \mathrm{ir}+\beta_{1} S N W I+\epsilon_{1} \\
& l e v^{s}(\mathrm{ir})=\alpha_{2}+\gamma_{2} \mathrm{ir}+\beta_{2} S N W I+\epsilon_{2}
\end{aligned}
$$

The data set only provides us with information on the equilibrium value of leverage, lev, and the equilibrium interest rate of each firm's most recent loan, ir, equating demand and supply.

$$
l e v=l e v^{s}(i r)=l e v^{d}(i r)
$$

Using this equilibrium condition, we can equate the demand- and supply-side value of leverage in (1) and (2) and solve for the reduced form of the interest rate.

$$
i r=\frac{\alpha_{2}-\alpha_{1}}{\gamma_{1}-\gamma_{2}}+\frac{\beta_{2}-\beta_{1}}{\gamma_{1}-\gamma_{2}} S N W I+\frac{\epsilon_{2}-\epsilon_{1}}{\gamma_{1}-\gamma_{2}}
$$

Equivalently, introducing new notation for the coefficients that can be identified, the reduced form can be written as:

$$
i r=\pi_{11}+\pi_{12} S N W I+\nu_{1}
$$

We will now describe our expectations concerning the signs of the coefficients in the structural form in order to deduce predictions for the signs in the reduced form. We can test the predictions for the reduced form with out data. In standard demand equations the demand of a good decreases in its price. There is no evidence in the literature that demand for external financing would behave in a non-standard way. We therefore expect that $\gamma_{1}$ in equation (1) is negative $]^{3}$ Since underdiversification increases the cost of equity capital,

\footnotetext{
${ }^{2}$ We proceed here according to the excellent discussion of simultaneous equations models in Wooldridge (2002, p. 209ff.).

${ }^{3}$ Freixas and Rochet (1997, p. 140) choose a standard demand function for loans in their theoretical discussion of credit rationing. Furthermore, information contained in the SSBF suggests a standard demand function as well. $16 \%$ of respondents mention a low interest rate as reason for choosing the bank from which they obtained their most recent loan. The only reason with higher importance is a long-term relationship or personal contacts ( $23 \%$ of respondents).
} 
we expect more underdiversified owners to have a higher demand for leverage ( $\beta_{1}$ positive). For the supply equation we need to differentiate two situations: First, it is possible that supply of external financing increases in the interest rate. In this case $\gamma_{2}$ is positive. Second, supply of external financing may be insensitive to the interest rate. Problems of asymmetric information can lead banks to adjust interest rates to the riskiness of a company only to a certain degree. Companies with higher leverage have a higher financial risk, but it can be profit maximising for banks not to charge higher interest rates for them. On the one hand, there is a problem of adverse selection. If interest rates are high it may be only worthwhile for entrepreneurs with low quality projects to apply for a loan. On the other hand, there is a moral hazard problem. With high interest rates entrepreneurs have more incentives to increase the risk of the project after they have obtained a loan. If the problems of adverse selection are severe and if the bank has not enough funds to serve all loan applicants at the profit maximising interest rate, a situation of credit rationing can obtain (Stiglitz and Weiss (1981)). The implications of a price-insensitive supply function for $\gamma_{2}$ can best be illustrated by first solving the supply of leverage (2) for the interest rate:

$$
i r^{s}(\mathrm{lev})=-\frac{\alpha_{2}}{\gamma_{2}}+\frac{1}{\gamma_{2}} \mathrm{lev}-\frac{\beta_{2}}{\gamma_{2}} S N W I-\frac{1}{\gamma_{2}} \epsilon_{2}
$$

If the interest rate is not adjusted to the degree of leverage, then the coefficient of leverage will be zero. In this case $\gamma_{2}$ in equation (2) is one divided by zero, i.e. positive infinity. The last remaining coefficient to be signed is $\beta_{2}$. Considering the better performance of companies with underdiversified owners, we expect that, in a competitive environment, banks offer a larger volume of financing to more underdiversified owners ( $\beta_{2}$ positive).

For the case of a standard supply function, i.e. $\gamma_{2}$ finite positive, the sign of $\pi_{12}$ in the reduced form (5) depends on the relative extent of the demand and supply shifts due to SNWI. The term $\gamma_{1}-\gamma_{2}$ in the denominator is always negative. $\beta_{2}$ relates to the shift in the supply function and $\beta_{1}$ relates to the shift in the demand function. If the shift in the supply function exceeds that of the demand function $\left(\beta_{2}-\beta_{1}\right.$ positive), then $\pi_{12}$ is negative and a lower interest rate is predicted for higher values of underdiversification. However, if the shift in the demand function exceeds the shift in the supply function $\left(\beta_{2}-\beta_{1}\right.$ negative), the relationship between underdiversification and interest rate will be positive. Intuitively, there are two conflicting influences at work. On the one hand, underdiversification can 
function as a signal of company profitability, hence decreasing the interest rate charged by banks. Mueller (2004) shows that underdiversification leads to higher company profitability because owners require a higher return for selected projects and owners who are at the same time managers work harder to ensure the success of the company. On the other hand, more highly underdiversified owners face higher costs of capital and are therefore willing to pay higher interest rates in order to obtain bank loans. In the case of a price-insensitive supply function SNWI has no effect on the interest rate, i.e. $\gamma_{2}$ infinity, we expect no influence of SNWI on the interest rate.

Hypothesis 3 (interest rate): With a standard supply function the relationship between the interest rate on a firm's most recent loan and underdiversification is ambiguous. If the shift in the demand curve is smaller (larger) than the shift in the supply curve, then SNWI will have a negative (positive) effect on the interest rate. With a price-insensitive supply function SNWI has no effect on the interest rate.

For the equilibrium value of leverage it is possible to derive an unambiguous prediction. After multiplying equations (1) and (2) by $\gamma_{2}$ and $\gamma_{1}$ respectively, we solve both equations for $\gamma_{1} \gamma_{2} i r$, set them equal and solve for the equilibrium value of leverage, lev. We thus obtain the reduced form for leverage:

$$
l e v=\frac{\gamma_{1} \alpha_{2}-\gamma_{2} \alpha_{1}}{\gamma_{1}-\gamma_{2}}+\frac{\gamma_{1} \beta_{2}-\gamma_{2} \beta_{1}}{\gamma_{1}-\gamma_{2}} S N W I+\frac{\gamma_{1} \epsilon_{2}-\gamma_{2} \epsilon_{1}}{\gamma_{1}-\gamma_{2}}
$$

Or simplified:

$$
l e v=\pi_{21}+\pi_{22} S N W I+\nu_{2}
$$

We first discuss the case of a finite $\gamma_{2}$. According to the discussion of the signs of $\gamma_{1}, \beta_{1}$, $\gamma_{2}$ and $\beta_{2}$, it follows that $\pi_{22}$ will be positive: $\gamma_{1}-\gamma_{2}$ is always negative, the term $\gamma_{1} \beta_{2}$ is negative, and the term $\gamma_{2} \beta_{1}$ is positive. We therefore expect a positive relationship between underdiversification and leverage in the reduced form. Both demand and supply factors tend to indicate greater leverage for higher values of SNWI. We also obtain this prediction in the

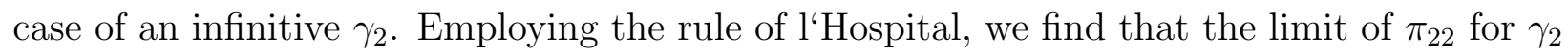
infinity is equal to $\beta_{1}$ and therefore positive. 
Hypothesis 4 (leverage): Companies whose owners have a higher degree of underdiversification have greater leverage.

\section{Data}

The Survey of Small Business Finances 1998 (SSBF), which is conducted by the Board of Governors of the Federal Reserve System, Washington, DC, is used for the empirical analysis. The survey provides information on 3,561 private companies with up to 500 employees from non-agricultural and non-financial sectors in the US. This survey is well suited for our study because it provides information both on the financial situation of a private company and on the personal wealth of its largest owner. The survey has a detailed section on bank financing. We learn whether companies have applied for bank loans in the years prior to the survey, whether they were successful with their applications and, if successful, what interest rate they had to pay. The investigation is restricted to the survey's 1998 edition since those previous do not include information on the personal wealth of the largest owner $4^{4}$

The main concern of this paper is the influence of underdiversification on the capital structure of private companies. We measure underdiversification as the ratio of the largest owner's equity investment to the net worth of the largest owner, i.e., as the share of net worth invested (SNWI). Net worth is defined as the book value of the equity investment plus the equity value of the primary residence plus the sum of all assets minus the sum of all other liabilities of the largest owner.

Two measures of underdiversification are calculated. The first measure, denoted with SNWI A, considers only the value of the equity investment.

$$
\text { SNWI A }=\frac{\text { (ownership share } * \text { book value of equity) }}{\text { net worth }}
$$

The second measure, SNWI B, takes into account that the equity investment is not the only way in which the owners' assets are tied to the company. Owners can also give personal guarantees for company loans, use private assets as collateral and extend loans to the company. The survey includes information on the extent of these activities for all of the owners

\footnotetext{
${ }^{4}$ Detailed information on the 1998 SSBF survey is available in Bitler et al. (2001).
} 
combined. This information is therefore multiplied by the ownership share of the largest owner to produce an approximation of that owner's personal involvement.

$$
\begin{gathered}
\text { SNWI B }= \\
\frac{\text { ownership share } *(\text { book value of equity }+ \text { guarantees }+ \text { collateral }+ \text { loans })}{\text { net worth }}
\end{gathered}
$$

The measures SNWI A and SNWI B document a considerable degree of underdiversification. SNWI A has an average of 25.8\%. By additionally considering guarantees, collateral and loans, the average value of SNWI B increases by six percentage points.

Share of net worth invested is an approximation of the risk exposure of owners due to their equity investment in a private company. Owners are exposed to several types of risk. For example, there is a concentration of income from one source and the possibility that the value of the ownership share could fall. These risks certainly increase with SNWI. However, in order to completely describe the risk exposure of owners, it would be necessary to have information on all assets in the owners' portfolio and the correlation structure of their returns. For instance, if an owner has invested in the stock market and the returns on his or her private company exhibit a negative correlation with the returns on the stock market, his or her risk exposure is lower compared to a situation in which returns are positively correlated. Since the survey has no information from which the correlation of returns could be deduced, we must rely on size of equity investment relative to net worth as a proxy for risk exposure. We use industry dummies to control for return characteristics of private equity that are identical within an industry: $!^{5}$

The survey covers the demand for and the supply of loans at the company level. The variable loan application is equal to 1 if an application for a new loan had been filed in the three years preceding the survey and 0 otherwise. Loan renewals are not counted. Loan approval is set equal to 1 if the loan applications filed by the company in question in the three years preceding the survey had always been approved. It is coded as 0 if at least one

\footnotetext{
${ }^{5}$ SNWI can be used as a measure of underdiversification for owners with limited and unlimited liability. Even owners with unlimited liability lose only their equity investment in the case of bankruptcy if their private assets are below exemption limits stipulated by bankruptcy laws. According to Fan and White (2003, p. 3) this is often the case.
} 
loan application has been denied. Companies which have not applied for a new loan in the last three years are not included in this variable.

Besides the variable for underdiversification, SNWI, we use ownership share as control variable when investigating loan applications and loan approvals. Ownership share is defined as the share of equity owned by the largest owner. We also control for company size, measured by number of employees, and company age, defined as the number of years since the company was founded or acquired. All regressions include industry dummies defined at the 1-digit SIC level, the entrepreneurial work experience of the largest owner, measured as number of years owning or managing a company, and dummies for legal form differentiating between sole proprietorships, partnerships, S- and C-corporations. ${ }^{6}$

As is described in detail in the next subsection, we need to control for potential endogeneity of some regressors. We employ specific characteristics of the owner and the company as instruments. Owner age is the age of the largest owner measured in years. Owner sex dummy takes the value 1 for female owners and the value 0 for male owners. The type of company acquisition is also used. 'Company founded' is the base category; company purchased and company inherited is covered by dummies.

We estimate reduced forms for the cost of a bank loan and for the leverage of a company. Interest rate is the nominal interest rate the company has to pay for its most recent loan. The lowest and highest $1 \%$ of the observations are trimmed in order to eliminate implausible values. Risk premium is defined as the difference between the interest rate on a company's most recent loan and the yield of a US government security with the same maturity as the loan. This variable covers only the portion of the interest rate that exceeds the cost of a riskless loan.

We include three controls in the interest rate regressions that are meant to capture the economy-wide interest rate level at the time of loan application. The variable default spread reflects the market price for risk in corporate bonds. It is defined as the difference between the average yield on corporate bonds rated 'Baa' by Moody's and the yield on US government securities with a ten year maturity. The prime rate is included as a general

\footnotetext{
${ }^{6} \mathrm{C}$ - and S-corporations are both characterised by limited liability. C-corporations have to pay corporation tax for profits that are paid out to the shareholders, whereas profits of S-corporations are only charged with the personal income tax rate of their owners.
} 
control for the price of corporate bonds. It is defined by The Wall Street Journal as "the base rate on corporate loans posted by at least $75 \%$ of the nation's 30 largest banks". It is the risk-free rate plus the risk premium for a bank's best customers. The variable term structure spread is the difference between the yield of a US government security of the same maturity as a company's loan minus the yield of a US government security with a one year maturity. This variable is set to zero for loans with a variable interest rate and for loans without fixed maturity. Information on the three controls for the economy-wide interest level is obtained from the FRED II database provided by the Federal Reserve Bank of St. Louis. This database can be accessed via http://research.stlouisfed.org/fred2/.

Finally, for the reduced form of leverage, we define leverage as the sum of all liabilities of the company divided by its total assets (sum of equity and liabilities).

Only companies with positive equity values are included in the analysis because it is otherwise not possible to derive SNWI 7 In addition, companies are required to have positive sales and assets and owners are required to have positive private wealth. 2,666 companies are eventually included in the analysis. Descriptive statistics for all of the variables can be found in Table $\mathrm{A}$ in the appendix. Table $\mathrm{B}$ in the appendix provides an overview of the distribution of the companies according to industry.

\section{Empirical Results}

\subsection{Endogeneity of Regressors}

In the empirical analysis we need to be concerned with the potential endogeneity of the regressors share of net worth invested (SNWI) and ownership share. This can be illustrated for the case of the leverage regression. First, there is the problem of reverse causality. Owners may adapt the share of net worth invested (SNWI) in response to the availability of bank loans. Better companies may find it easier to obtain bank loans, which will allow their owners to grow the company without increasing equity. Reverse causality introduces

\footnotetext{
${ }^{7} 21 \%$ of the companies have negative equity values. Equity value is not requested explicitly in the survey but is calculated as the difference of the company's total assets and liabilities. It is possible that assets are under- or liabilities over-reported because most respondents are not required by law to draw up a balance sheet.
} 
a negative relationship between leverage and SNWI. Part of this reverse causality problem would be mitigated if we could perfectly control for company quality. The ownership share of a firm's largest owner can also be influenced by the availability of bank loans and, as a result, by leverage. If bank financing is not available and a firm's original owner has too few resources to meet the total investment required, it may be necessary to take on an additional owner.

Second, we need to be wary of measurement error. Most of the small companies included in the SSBF are not required by law to draw up a balance sheet. Therefore, the measurement of the assets and liabilities of these companies will be imprecise; leverage will be measured with error. Furthermore, since book value of equity is not requested explicitly but calculated as the difference between total assets and total liabilities, the measurement error is transferred to the regressor SNWI. $]^{8}$

To deal with the mentioned problems of endogeneity we use specific owner and company characteristics as instruments of SNWI and ownership share. Table 1 shows the first stage regression results. The first instrument is the age of the largest owner. Heaton and Lucas (2000) show that investment in private equity changes with age; this instrument should thus be related to SNWI. From columns (1) and (2) it can be seen that owner age, measured in years, has a significant negative influence on underdiversification. Older owners have had more time to build up wealth outside the company by saving from income. The income can be either from a company or wage income from employment. Underdiversification will therefore be lower for more experienced entrepreneurs. Since experience can be related to our dependent variables, we need to directly control for the work experience of the largest owner in the second stage regression. It is to be expected, for example, that more experienced owners will find it easier to obtain bank loans. By using experience as an explicit control, we use only the part of SNWI that can be explained by age excluding the years already spent as entrepreneur.

Further instruments are owner sex and type of company acquisition. These variables can affect owners' financial involvement, but since the regressions contain many controls for company characteristics such as size and age, they should be unrelated to the financial struc-

\footnotetext{
${ }^{8}$ This measurement error is non-standard because the same error is affecting both the dependent and an independent variable.
} 
Table 1: First Stage Regression Results

\begin{tabular}{lccc}
\hline Dep. variable: & SNWI A & SNWI B & Ownership share \\
\hline \hline Owner age & $(1)$ & $(2)$ & $(3)$ \\
& $(0.058)$ & $(0.066)$ & -0.078 \\
Owner sex dummy & $-2.68^{* *}$ & $-3.55^{* * *}$ & $(.050)$ \\
& $(1.18)$ & $(1.32)$ & -0.987 \\
Company purchased & $5.35^{* * *}$ & $5.86^{* * *}$ & $(0.933)$ \\
& $(1.25)$ & $(1.42)$ & -1.40 \\
Company inherited & $7.12^{* * *}$ & $5.40^{* *}$ & $(1.15)$ \\
& $(2.15)$ & $(2.38)$ & $-3.65^{*}$ \\
\hline Number of observations & 2666 & 2666 & $(2.10)$ \\
Joint significance of & & & 2666 \\
excluded instruments, $\chi^{2}(4)$ & $68.2^{* * *}$ & $72.4^{* * *}$ & $8.00^{*}$ \\
Shea's partial R squared & 0.028 & 0.028 & 0.003 \\
R squared & 0.126 & 0.169 & 0.425 \\
\hline \hline
\end{tabular}

Note: * **, *** indicate statistical significance at the 10, 5, and 1 percent levels, respectively. Robust standard errors are in parentheses. The regressions contain additional controls for company size, company age, industry, experience and legal form.

ture of each company. The owner sex dummy shows that women are less underdiversified. Owners who purchased or inherited their company are more underdiversified than founding owners. When founding a company, owners have the opportunity to choose a more limited investment. These instruments are individually significant at least at the $5 \%$ level and are jointly significant at the $1 \%$ level. In contrast, the instruments for ownership share of the largest owner are quite weak. As can be seen from column (3), the only significant effect is a reduced ownership share for companies that have been inherited. The negative effect is plausible since ownership will often be divided between several heirs. The instruments are jointly significant to only the $10 \%$ level. In addition, Shea's partial R squared (see Shea (1997)) is very low at 0.003 . The weak instruments make it difficult to establish an influence of ownership share in the second stage regressions. However, in this paper's analysis this regressor is only of secondary interest. 


\subsection{Demand for Bank Loans}

Underdiversification sharply increases the cost of equity capital because it exposes owners to idiosyncratic risk for which they may require a compensation. More underdiversified owners can therefore be expected to express a higher demand for bank loans as an alternative source of financing. This is the prediction of Hypothesis 1, which we test in this subsection. Bank loans allow underdiversified owners to reduce their financial exposure to the company.

Table 2 presents probit regressions on demand for bank loans. The dependent variable 'loan application' is equal to 1 if an application for a new loan had been filed in the three years preceding the survey and 0 otherwise. For the probit regressions including instrumented endogenous regressors, we follow the approach developed by Newey (1987). Both measures of underdiversification are used as controls. SNWI A only considers equity investment when calculating degree of financial exposure, whereas SNWI B additionally includes personal assets used as collateral, personal guarantees for company loans and loans to the company. We only report one specification with SNWI B since the signs of the coefficients and the significance levels are always identical for SNWI A and SNWI B.

The OLS specification in column (1) shows a higher demand for bank loans for owners with higher values of SNWI, but the result is affected by reverse causality. If owners decide, for whatever reason, not to use bank loans as a means of financing their company, they must rely more heavily on their own resources; this increases SNWI. The negative coefficient of ownership share may have several reasons, one being differences in capital intensity. A high capital intensity may simultaneously lead to a smaller ownership share of the largest owner, since the contributions of several owners are needed, and to a higher demand for external financing. The results also show that larger and younger companies exhibit a higher demand for new loans.

In the IV regressions in columns (2) to (4) we control for reverse causality. The basic specification in column (2) supports Hypothesis 1; SNWI increases the probability of loan applications. Owners with a higher degree of underdiversification approach banks more often in order to obtain additional funds. Specifically, a one standard deviation increase in SNWI A leads, ceteris paribus, to an increase of 30.6 percentage points in probability of loan application. As in the data set probability of applying for a new loan is only $25.4 \%$, the influence of underdiversification is quite substantial. The coefficient of ownership share is 
Table 2: Probit Estimations - Demand for New Loans

\begin{tabular}{|c|c|c|c|c|}
\hline \multirow[t]{2}{*}{ Dep. variable } & \multicolumn{4}{|c|}{ Loan application } \\
\hline & $(1)$ & $(2)$ & $(3)$ & $(4)$ \\
\hline & OLS & IV & IV & IV \\
\hline \multirow[t]{2}{*}{ SNWI A } & $0.534^{* * *}$ & $3.91^{* * *}$ & $3.09^{* * *}$ & \\
\hline & $(0.110)$ & $(1.03)$ & $(0.829)$ & \\
\hline \multirow[t]{2}{*}{ SNWI B } & & & & $3.43^{* * *}$ \\
\hline & & & & $(0.795)$ \\
\hline \multirow[t]{2}{*}{ Ownership share } & $-0.219^{*}$ & $5.70^{*}$ & 4.24 & 3.78 \\
\hline & $(0.124)$ & $(3.33)$ & $(2.85)$ & $(2.98)$ \\
\hline \multirow[t]{2}{*}{ Leverage } & & & $1.50^{* * *}$ & \\
\hline & & & $(0.157)$ & \\
\hline \multirow[t]{2}{*}{ Company size } & $0.0019^{* * *}$ & 0.0035 & 0.0021 & 0.0013 \\
\hline & $(0.0005)$ & $(0.0031)$ & $(0.0027)$ & $(0.0030)$ \\
\hline \multirow[t]{2}{*}{ Company age } & $-0.0122^{* * *}$ & -0.0038 & -0.0024 & -0.0030 \\
\hline & $(0.0030)$ & $(0.0065)$ & $(0.0057)$ & $(0.0058)$ \\
\hline Number of observations & 2666 & 2666 & 2666 & 2666 \\
\hline Pseudo R squared & 0.052 & 0.056 & 0.094 & 0.056 \\
\hline
\end{tabular}

Note: $*, * *, * * *$ indicate statistical significance at the 10,5 , and 1 percent levels, respectively. Standard errors are in parentheses. The dependent variable 'loan application' equals 1 if an application for a new loan had been filed in the three preceding years. SNWI and ownership share are instrumented in the IV specifications. SNWI, ownership share and leverage are expressed as ratios. The regressions also include controls for industry, experience and legal form.

now positive at a marginal significance level. Owners who choose a high personal ownership share to have control over the company may need more bank financing for their investment opportunities.

The additional specifications are intended as a robustness check. In column (3) we include a control for leverage. Companies with higher leverage - i.e., companies who have more often applied for loans in the past - are more likely to apply for new loans in the present as well. In column (4) we employ our second measure of underdiversification, SNWI B. Both 
modifications confirm that underdiversification increases demand for bank loans. Overall, we find evidence that is consistent with the idea that owners try to lighten the burden of underdiversification by more extensive use of bank financing.

\subsection{Supply of Bank Loans}

The success of loan applications can be influenced by the underdiversification of owners, since underdiversification increases companies' profitability (Mueller (2004)). The mechanisms identified by the author are higher required returns as a compensation for the exposure to idiosyncratic risk and increased effort. Since banks gain from higher profitability but do not suffer a disutility from the underdiversification of the owners, Hypothesis 2 postulates a positive effect of underdiversification on loan approvals. We use the information from the SSBF data on whether the companies' applications for new loans were successful. The dependent variable of the probit regressions in Table 3 is set equal to 1 if the loan applications filed by the company in question in the three previous years had always been approved and equal to 0 if at least one loan application has been denied. Companies without an application for a new loan are not considered in this analysis.

The OLS results in column (1) display a significant negative relationship between SNWI and approval of loan applications. However, this result is likely driven by reverse causality. If a loan application is not approved and the owner concerned wishes to proceed with the investments as originally planned, one option is to use his or her own resources instead. This contributes to the negative relationship between loan approvals and SNWI. Of the other regressors, both company size and company age have a positive influence on loan approvals. Banks are more likely to extend loans to larger and older companies because they are less risky.

After we eliminate the reverse causality effect by instrumenting SNWI and ownership share in columns (2) to (4), we find that SNWI is unrelated to loan approvals. This is not necessarily evidence that banks do not consider SNWI for their loan decisions because we cannot detect signalling strategies here. In the IV regressions we only use the aspects of SNWI that can be explained with instruments. These aspects are unrelated to company profitability. However, signalling company quality with SNWI relies precisely on the portion of SNWI that cannot be mechanically explained with factors unrelated to company prof- 
Table 3: Probit Estimations - Supply of New Loans

\begin{tabular}{|c|c|c|c|c|}
\hline \multirow{2}{*}{ Dep. variable } & \multicolumn{4}{|c|}{ Loan approval } \\
\hline & $(1)$ & $(2)$ & $(3)$ & $(4)$ \\
\hline & OLS & IV & IV & IV \\
\hline \multirow[t]{2}{*}{ SNWI A } & $-0.503^{* *}$ & -1.06 & -1.49 & \\
\hline & $(0.224)$ & $(2.45)$ & $(1.99)$ & \\
\hline \multirow[t]{2}{*}{ SNWI B } & & & & -0.856 \\
\hline & & & & $(1.63)$ \\
\hline \multirow[t]{2}{*}{ Ownership share } & -0.172 & -1.88 & -2.26 & -1.54 \\
\hline & $(0.270)$ & $(2.43)$ & $(2.37)$ & $(2.25)$ \\
\hline \multirow[t]{2}{*}{ Leverage } & & & 0.165 & \\
\hline & & & $(0.480)$ & \\
\hline \multirow[t]{2}{*}{ Company size } & $0.0048^{* * *}$ & 0.0040 & 0.0039 & 0.0043 \\
\hline & $(0.0016)$ & $(0.0029)$ & $(0.0029)$ & $(0.0030)$ \\
\hline \multirow[t]{2}{*}{ Company age } & $0.0253^{* * *}$ & $0.0226^{* *}$ & $0.0223^{* *}$ & $0.0235^{* *}$ \\
\hline & $(0.0087)$ & $(0.0098)$ & $(0.0101)$ & $(0.0096)$ \\
\hline Number of observations & 676 & 676 & 676 & 676 \\
\hline Pseudo R squared & 0.120 & 0.113 & 0.122 & 0.113 \\
\hline
\end{tabular}

Note: *,**,*** indicate statistical significance at the 10,5 , and 1 percent levels, respectively. Standard errors are in parentheses. 'Loan approval' is coded as 1 if the considered company's loan applications had always been approved in the previous three years, and as zero if at least one had been denied. SNWI and ownership share are instrumented in the IV specifications. SNWI, ownership share and leverage are expressed as ratios. The regressions also include controls for industry, experience and legal form.

itability. We therefore need to leave the question of whether underdiversification increases probability of a loan approval open; we cannot determine a definite conclusion for Hypothesis 2. It is possible that underdiversification has no effect on loan approval or that it has a positive effect through a signalling strategy. For the other controls we determine a positive effect for company age but no effect for leverage. 


\subsection{Reduced Form for Interest Rate}

A priori, the effect underdiversification has on a bank loan's interest rate is not clear. A positive or negative effect of underdiversification is possible depending on whether the demand or the supply function for loans shifts more. We established empirically that demand for bank loans increases with underdiversification. For supply of bank loans we did not find an effect but could not rule out that it is positive. With the reduced form for the interest rate we can establish whether demand or supply dominate.

For the interest rate specification it is less clear whether instruments are required. With respect to reverse causality it can be argued that owners who only receive bank loans with high interest rates will find it relatively more attractive to invest their own money and will therefore have higher values of SNWI. The effect should, however, remain slight. The OLS specification has the advantage that it can detect whether owners use high values of SNWI to signal company quality in order to obtain cheaper loans.

Table 4 shows the reduced form for the interest rate. SNWI has a negative sign in the OLS regression in column (1), but no significant effect is discernable. A higher ownership share increases the interest rate. If a high ownership share is a sign that the owner values control, it is possible that such an owner is willing to pay a higher interest rate for a bank loan because this type of financing allows the owner to keep more control in an expansion. Larger companies obtain cheaper loans but company age is irrelevant. We also control for the economy-wide level of interest rates with default spread, prime rate and term structure spread. The variables help to identify the company-specific components of the interest rate but have no significant coefficients themselves. In addition, we control for many loan characteristics. The coefficients of these controls are not shown for brevity. The reduced form of the interest rate contains only information for companies that have been successful with their loan application. It is a sub sample of the companies included in the previous subsection on loan supply.

The remaining specifications apply instruments for SNWI and ownership share. The specifications in columns (2) and (3) take the interest rate of the considered company's most recent loan as their dependent variable, whereas the specifications in columns (4) and (5) use the loan's risk premium. The results in columns (2) to (5) are quite similar. Underdiversification has no significant effect on interest rate. The effect of SNWI on demand 
Table 4: Reduced Form for Cost of a Bank Loan

\begin{tabular}{|c|c|c|c|c|c|}
\hline \multirow[t]{2}{*}{ Dep. variable } & \multicolumn{3}{|c|}{ Interest Rate } & \multicolumn{2}{|c|}{ Risk Premium } \\
\hline & $(1)$ & $(2)$ & $(3)$ & $(4)$ & $(5)$ \\
\hline & OLS & IV & IV & IV & IV \\
\hline \multicolumn{6}{|l|}{ Company controls } \\
\hline \multirow[t]{2}{*}{ SNWI A } & -0.0043 & -0.0244 & & -0.0223 & \\
\hline & $(0.0031)$ & $(0.0425)$ & & $(0.0404)$ & \\
\hline \multirow[t]{2}{*}{ SNWI B } & & & -0.0286 & & -0.0269 \\
\hline & & & $(0.0338)$ & & $(0.0322)$ \\
\hline \multirow[t]{2}{*}{ Ownership share } & $0.0089^{* * *}$ & 0.0747 & $0.0823^{*}$ & 0.0651 & 0.0726 \\
\hline & $(0.0034)$ & $(0.0473)$ & $(0.0488)$ & $(0.0454)$ & $(0.0469)$ \\
\hline \multirow[t]{2}{*}{ Company size } & $-0.0031^{* *}$ & 0.0032 & 0.0046 & 0.0025 & 0.0039 \\
\hline & $(0.0013)$ & $(0.0052)$ & $(0.0054)$ & $(0.0050)$ & $(0.0053)$ \\
\hline \multirow[t]{2}{*}{ Company age } & -0.0144 & -0.0059 & -0.0054 & -0.0100 & -0.0096 \\
\hline & $(0.0093)$ & $(0.0159)$ & $(0.0164)$ & $(0.0149)$ & $(0.0154)$ \\
\hline \multicolumn{6}{|l|}{ Interest rate controls } \\
\hline \multirow[t]{2}{*}{ Default spread } & 0.0854 & 0.287 & 0.369 & $0.609^{* *}$ & $0.649 * *$ \\
\hline & $(0.418)$ & $(0.511)$ & $(0.541)$ & $(0.316)$ & $(0.334)$ \\
\hline \multirow[t]{2}{*}{ Prime rate } & 0.520 & $1.09 *$ & $1.10^{*}$ & & \\
\hline & $(0.471)$ & $(0.620)$ & $(0.642)$ & & \\
\hline \multirow[t]{2}{*}{ Term structure spread } & 0.188 & 0.962 & 1.06 & & \\
\hline & $(0.361)$ & $(0.671)$ & $(0.699)$ & & \\
\hline Number of observations & 570 & 570 & 570 & 570 & 570 \\
\hline $\begin{array}{l}\text { Overidentification test } \chi^{2} \\
\text { (dof, p-value) }\end{array}$ & & $\begin{array}{c}2.01 \\
(2,0.37)\end{array}$ & $\begin{array}{c}1.46 \\
(2,0.48)\end{array}$ & $\begin{array}{c}2.05 \\
(2,0.36)\end{array}$ & $\begin{array}{c}1.49 \\
(2,0.48)\end{array}$ \\
\hline
\end{tabular}

Note: * **, *** indicate statistical significance at the 10,5 , and 1 percent levels, respectively. Robust standard errors are in parentheses. The regressors SNWI and ownership share are instrumented. The regression contains the following characteristics of the loan: loan type, compensating balance required, guarantee required, collateral required and presence of fixed interest rate. The regressions also include controls for industry, experience and legal form. 
for and supply of leverage leads to a new equilibrium situation in which the interest rate remains largely unchanged. With respect to hypothesis 3 we can conclude that neither a shift in demand for nor in supply of leverage dominates. Ownership share is significant at the $10 \%$ level only in column (3). The controls for the economy-wide interest level are only partially significant. We find an influence of the prime rate in column (2) and (3) and an influence of the default spread in columns (4) and (5). The test of overidentifying restrictions is also shown in Table 4. It shows that the instruments are valid from a statistical point of view.

\subsection{Reduced Form for Leverage}

In this subsection we discuss the influence of underdiversification on the equilibrium value of leverage. We restrict our attention to a reduced form specification since we cannot identify demand and supply separately. From simulations of changes in the cost of equity capital using the CAPM and data on newly public companies by Kerins et al. (2004), we would expect a sizable positive effect of underdiversification on leverage. The authors calculate for small companies with 26-100 employees that a change in SNWI from $15 \%$ to $25 \%$ increases the cost of equity capital for an underdiversified entrepreneur by 9.8 percentage points. The cost of equity increases since the entrepreneur is more exposed to idiosyncratic risk of the company. This considerable change in the cost of equity capital should lead to large adjustments in the capital structure of private companies. In Hypothesis 4 we stipulate accordingly a positive influence of underdiversification on leverage. In the previous probit regressions we could establish that underdiversification increases the demand for new loans. For loan supply we found no effect or a positive effect. Taking changes in demand and supply together it is possible that underdiversification has a positive influence on leverage.

Table 5 displays the effect of underdiversification on leverage. The coefficient of SNWI is positive and significant to the $1 \%$ level. The influence of underdiversification on the equilibrium value of leverage is quite large. The calculation for the specification in column (1) shows that a one standard deviation increase in SNWI A leads, ceteris paribus, to an increase in leverage of 18.5 percentage points. This is substantial indeed, especially when considering that average leverage in the sample is $32.6 \%$. The empirical results clearly confirm Hypothesis 4: Underdiversification leads to a sizable increase in leverage. 


\begin{tabular}{lcc}
\hline Dep. variable: & \multicolumn{2}{c}{ Leverage } \\
\hline \hline & IV & $(1)$ \\
\hline SNWI A & $0.736^{* * *}$ & IV \\
SNWI B & $(0.222)$ & \\
& & $0.648^{* * *}$ \\
Ownership share & & $(0.163)$ \\
& 1.09 & 0.726 \\
Company size & $(0.738)$ & $(0.636)$ \\
& 0.095 & 0.053 \\
Company age & $(0.072)$ & $(0.065)$ \\
& -0.097 & -0.082 \\
\hline Number of observations & $(0.144)$ & $(0.119)$ \\
Overidentification test, $\chi^{2}$ & 2666 & 2666 \\
(dof, p-value) & 1.91 & 2.39 \\
\hline \hline
\end{tabular}

Note: $*, * *, * * *$ indicate statistical significance at the 10,5 , and 1 percent levels, respectively. Robust standard errors are in parentheses. The regressors SNWI and ownership share are instrumented. The regressions also include controls for industry, experience and legal form.

Ownership share has a positive but insignificant influence on leverage. The insignificance of the coefficient may be influenced by the weakness of the instruments applied to the ownership variable. The controls for company size and company age do not influence leverage either. In the IV regressions of the previous subsections we also found no influence of company size and age on the demand for and supply of loans with the exception of a positive influence of company age on loan supply. The test of overidentifying restrictions again confirms the statistical validity of the instruments.

Strebulaev (2004) cautions that in the presence of adjustment costs cross-sectional relationships between leverage and other variables determined by empirical analysis may differ from the relationships expected if variables are at their target level. The argument is illus- 
trated with the help of the trade-off theory which postulates a positive relationship between leverage an profitability since the interest paid can be deducted from profits for the calculation of taxes. Even if the trade-off theory es valid, we may still observe a negative relationship between leverage and profitability if profits are used to pay down loans and if leverage is adjusted infrequently. In our case, both leverage and SNWI is likely affected by adjustment costs. Higher profits will lead to lower leverage and, to a small degree, to lower values of SNWI which could introduce a positive relationship between the variables. However, this influence of profitability is removed from our analysis through the use of instruments which are unrelated to profitability.

\subsection{New Equilibrium Values for Leverage and the Interest Rate}

The empirical results from the previous sections can be used to infer characteristics of the demand for and supply of leverage in a structural model. The market constellation must exhibit an unchanged interest rate and increased leverage after an increase in SNWI. There are two possible constellations illustrated in panels A) and B) of Figure 1 that fulfill these conditions. The original demand and supply curves for leverage are denoted by D and S, while the demand and supply curves after an increase in SNWI are denoted by D' and S',9

Empirically, we cannot infer the slopes of demand and supply, $\gamma_{1}$ and $\gamma_{2}$. We need to work with assumptions with respect to their signs. The demand function is identical in panel A) and B). We assume a negative influence of the interest rate, i.e. a negative value for $\gamma_{1}$, since there is no indication that demand for leverage would behave in a non-standard way. Our probit regression on probability of loan application revealed a positive effect of SNWI, from which we conclude that higher values of SNWI lead to a higher demand for leverage, hence we confirmed our expectation that $\beta_{1}$ of the structural equation of the demand for leverage (1) is positive. For the structural equation of supply of leverage (2) we differentiate

\footnotetext{
${ }^{9}$ The whole analysis is performed under the ceteris paribus assumption. For example, the demand function shows how demand for leverage changes for different interest rates when SNWI is held constant. In practise, the additional loans that lead to an increase in leverage could be used to decrease equity; as a result, SNWI would decline. Alternatively, one can implicitly assume that additional loans are used to increase the total assets of a company and not to substitute equity capital. The shift in SNWI is also considered under the ceteris paribus assumption. Otherwise, a change in SNWI caused by a change in equity would also influence leverage if total debt did not change in the same proportion.
} 
Figure 1: Change in Market Equilibrium Consistent with Empirical Evidence

\section{A) Standard Supply Function}

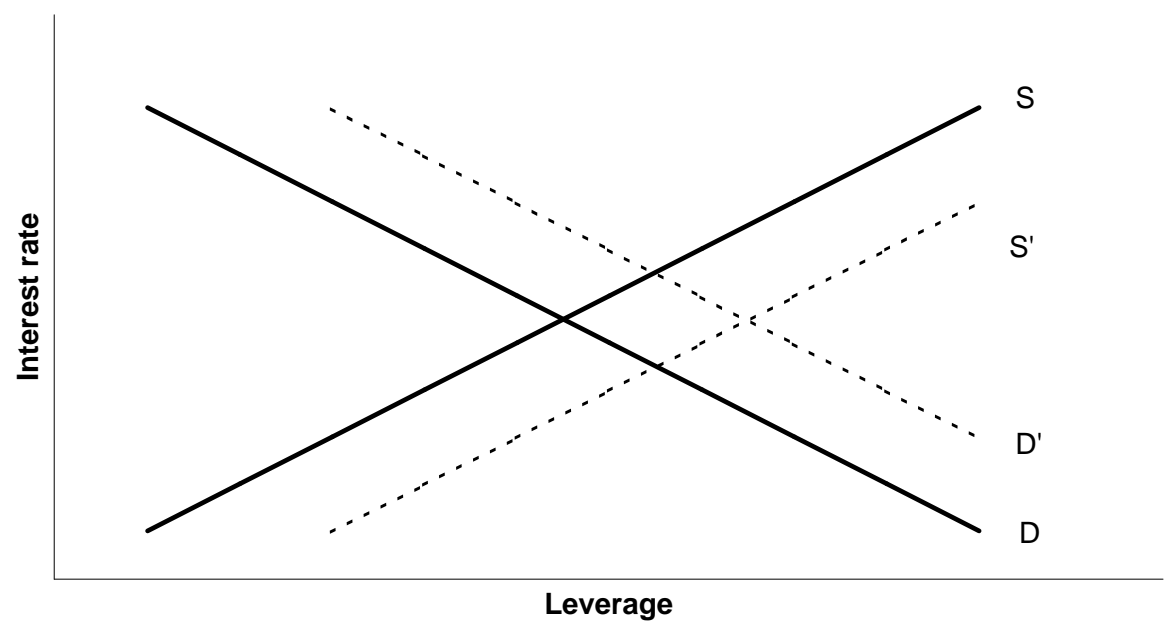

B) Supply Insensitive to Interest Rate

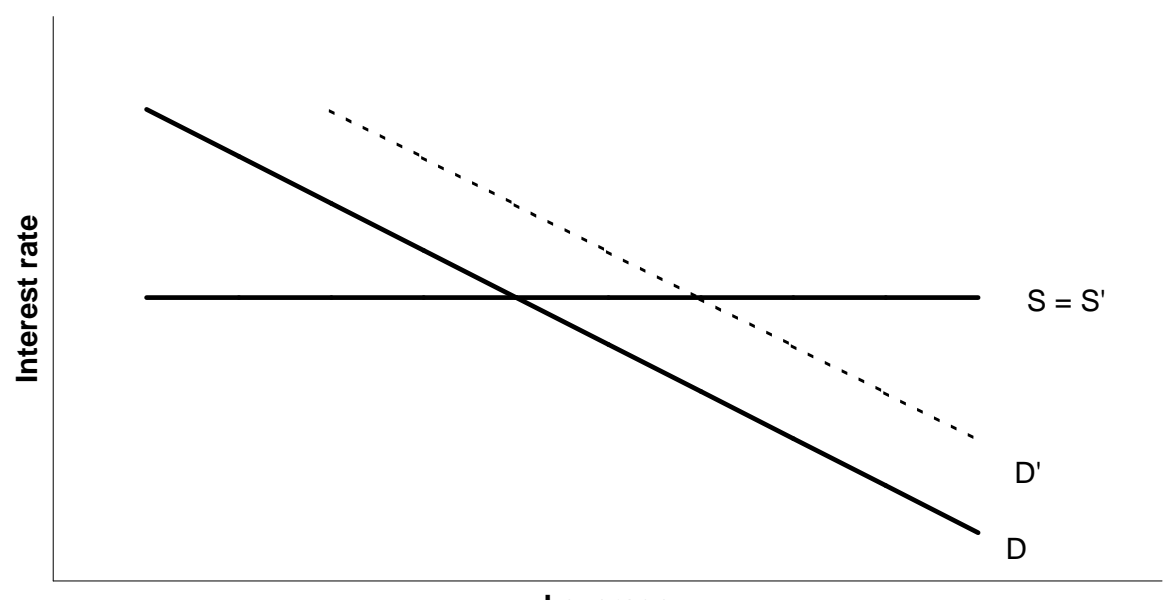

Leverage

two situations. First, panel A) depicts the situation of a finite $\gamma_{2}$. In this case the interest rate is an increasing function of leverage. In the equilibrium after an increase in SNWI we have no change in the interest rate, therefore the supply of leverage has to increase. In our empirical analysis we found no influence of SNWI on the probability of a loan approval. However, we could not exclude the possibility that owners use underdiversification as a signal of company quality. In this case $\beta_{2}$ is positive. Second, panel B) displays the situation of a 
price-insensitive supply function ( $\gamma_{2}$ infinity). The supply function is flat; the interest rate does not depend on the level of leverage 10 For this to be consistent with an unchanged interest rate, we need to have that underdiversification is not signalling company quality, i.e. $\beta_{2}$ equal to zero.

Overall, our empirical analysis finds that underdiversification leads to higher leverage through the channel of an increased demand. The empirical results have important implications for our understanding of the capital structure of private companies. We find that entrepreneurs who are more exposed to the idiosyncratic risk of their companies use bank financing more extensively. Bank financing allows them to grow their companies without increasing their risk exposure further. Alternatively, entrepreneurs can use bank financing to reduce their own investment. Since exposure to idiosyncratic risk increases the cost of equity capital and accordingly the required returns of an investment project, this also means that the availability of bank loans makes the realisation of some investment projects profitable that would not be realised in its absence.

\section{Conclusions}

The financing of private companies relies to a large extent on the personal resources of their owners. Equity investments often amount to a substantial share of owners' total net worth, which leads to underdiversification in their overall portfolios. Since the underdiversification of owners increases the cost of equity capital substantially, it should have an important influence on the capital structure of private companies. If owners try to equalise the marginal cost of equity and debt financing, companies led by more highly underdiversified owners should use higher values for leverage. This is the core hypothesis tested in this paper.

Using survey data on private companies in the US, we find that underdiversification increases demand for loans, measured as probability of loan application. For supply of loans we find no effect of underdiversification, but we cannot exclude the possibility that underdiversification increases the supply of loans through a signalling mechanism. We also

\footnotetext{
${ }^{10}$ The supply function in panel B) is drawn as solid line. This suggests that banks hardly vary the interest rate for different volumes of external financing which they provide. However, in a situation of credit rationing it would also be possible that companies do not obtain the full amount demanded at the given interest rate.
} 
discuss how underdiversification affects equilibrium values of interest rates charged for new loans and leverage. Interest rates are not influenced by underdiversification, possibly because banks are unwilling to increase interest rates in response to higher demand for bank loans. The higher demand for new loans is manifest in higher values for leverage in companies whose owners are more underdiversified. This paper identifies underdiversification of owners as a statistically and economically important influence on the capital structure of private companies.

In future research it would be of interest to test whether the effect of underdiversification on leverage found for private companies also exists for public companies. On theoretical grounds, we would also expect an effect for public companies with a concentrated ownership structure. It may be possible to use public companies in which families or founders hold high ownership shares for a corresponding test. 


\section{References}

Ang, J. S., Cole, R. A. and Lin, J. W. (2000), 'Agency Costs and Ownership Structure', Journal of Finance 55, 81-106.

Berger, A. N. and Udell, G. F. (1995), 'Relationship Lending and Lines of Credit in Small Firm Finance', Journal of Business 68, 351-381.

Bitler, M. P., Moskowitz, T. J. and Vissing-Jørgensen, A. (2005), 'Testing Agency Theory With Entrepreneur Effort and Wealth', Journal of Finance (forthcoming).

Bitler, M. P., Robb, A. M. and Wolken, J. D. (2001), 'Financial Services Used by Small Businesses: Evidence from the 1998 Survey of Small Business Finances', Federal Reserve Bulletin 87, 183-205.

Cavalluzzo, K. and Wolken, J. (2002), 'Small Business Loan Turndowns, Personal Wealth and Discrimination', FEDS Working Paper No. 2002-35.

Chittenden, F., Hall, G. and Hutchinson, P. (1996), 'Small Firm Growth, Access to Capital Markets and Financial Structure: Review of Issues and an Empirical Investigation', Small Business Economics 8, 59-67.

Cressy, R. (1996), 'Commitment Lending Under Asymmetric Information: Theory and Tests on U.K. Startup Data', Small Business Economics 8, 397-408.

Fan, W. and White, M. J. (2003), 'Personal Bankruptcy and the Level of Entrepreneurial Activity', Journal of Law and Economics 46, 543-568.

Freixas, R. and Rochet, J.-C. (1997), Microeconomics of Banking, MIT Press, Cambridge.

Giannetti, M. (2003), 'Do Better Institutions Mitigate Agency Problems? Evidence from Corporate Finance Choices', Journal of Financial and Quantitative Analysis 38, 185212.

Heaton, J. and Lucas, D. (2000), 'Portfolio Choice and Asset Prices: The Importance of Entrepreneurial Risk', Journal of Finance 55, 1163-1198. 
Kerins, F., Smith, J. K. and Smith, R. (2004), 'Opportunity Cost of Capital for Venture Capital Investors and Entrepreneurs', Journal of Financial and Quantitative Analysis $39,385-406$.

Moskowitz, T. J. and Vissing-Jørgensen, A. (2002), 'The Returns to Entrepreneurial Investment: A Private Equity Premium Puzzle?', American Economic Review 92, 745-778.

Mueller, E. (2004), 'Underdiversification in Private Companies - Required Returns and Incentive Effects', ZEW Discussion Paper No. 04-29, Mannheim.

Newey, W. (1987), 'Efficient Estimation of Limited Dependent Variable Models With Endogenous Explanatory Variables', Journal of Econometrics 36, 231-250.

Petersen, M. and Rajan, R. G. (1994), 'The Benefits of Lending Relationships: Evidence from Small Business Data', Journal of Finance 49, 3-37.

Shea, J. (1997), 'Instrument Relevance in Multivariate Linear Models: A Simple Measure', Review of Economics and Statistics 79, 348-352.

Stiglitz, J. E. and Weiss, A. (1981), 'Credit Rationing in Markets with Imperfect Information', American Economic Review 71, 393-409.

Strebulaev, I. (2004), 'Do Tests of Capital Structure Theory Mean What They Say?', Working Paper, London Business School.

Wooldridge, J. M. (2002), Econometric Analysis of Cross Section and Panel Data, MIT Press, Cambridge, Massachusetts. 


\section{Appendix}

Table A: Descriptive Statistics

\begin{tabular}{|l|c|c|c|c|c|}
\hline Variable & Mean & Median & Stdev. & Min & Max \\
\hline \hline \multicolumn{1}{|c|}{ Company information } & & & & & \\
Number of employees & 27.6 & 5 & 57.1 & 1 & 482 \\
Company age (in years) & 15.2 & 12 & 12.5 & 1 & 104 \\
Loan application & 0.254 & 0 & 0.436 & 0 & 1 \\
Loan approval & 0.769 & 1 & 0.422 & 0 & 1 \\
Interest rate of most recent loan (in \%) & 8.90 & 8.75 & 2.05 & 2.00 & 16.00 \\
Risk premium of most recent loan (in \%) & 3.46 & 3.32 & 2.10 & -3.62 & 10.8 \\
Leverage (in \%) & 32.6 & 25.6 & 31.1 & 0 & 99.8 \\
\hline Owner information & & & & & \\
Net worth (in million US-\$) & 1.50 & 0.416 & 4.38 & 0.0001 & 116 \\
SNWI A (in \%) & 25.8 & 17.8 & 25.1 & 0.004 & 100 \\
SNWI B (in \%) & 31.6 & 21.9 & 29.7 & 0.01 & 100 \\
Ownership share largest owner (in \%) & 80.0 & 100 & 27.6 & 1 & 100 \\
Experience of owner (in years) & 19.7 & 19.0 & 11.8 & 0 & 72 \\
Owner age (in years) & 51.2 & 51 & 11.3 & 21 & 95 \\
Owner sex dummy & 0.22 & 0 & 0.41 & 0 & 1 \\
\hline Economy-wide interest rate information & & & & & \\
Prime rate (in \%) & 8.22 & 8.25 & 0.33 & 7.75 & 9.00 \\
Term structure spread (in \%) & 0.30 & 0.23 & 0.31 & -0.16 & 1.4 \\
Default spread (in \%) & 2.12 & 0.36 & 1.45 & 2.65 \\
\hline
\end{tabular}

Note: Descriptive statistics refer to the sample information without weighting. The displayed statistics reflect the variation in the sample, but are not representative of the US economy. 
Table B: Industry Distribution

\begin{tabular}{|l|c|c|}
\hline Industry & No. of companies & \% of companies \\
\hline \hline SIC 1 - Mining, construction & 261 & 9.8 \\
SIC 2 - Manufacturing & 130 & 4.9 \\
SIC 3 - Manufacturing & 178 & 6.7 \\
SIC 4 - Transp., communication, utilities & 96 & 3.6 \\
SIC 5 - Retail trade & 736 & 27.6 \\
SIC 6 - Real estate & 153 & 5.7 \\
SIC 7 - Services & 623 & 23.4 \\
SIC 8 - Services & 489 & 18.3 \\
\hline Total & 2666 & 100 \\
\hline
\end{tabular}

Note: Descriptive statistics refer to the sample information without weighting. The displayed statistics reflect the variation in the sample, but are not representative of the US economy. 